\title{
Quality of buffalo milk as affected by dietary protein level and flaxseed supplementation
}

\author{
A. Santillo, ${ }^{1}$ M. Caroprese, R. Marino, A. Sevi, and M. Albenzio \\ Department of the Sciences of Agriculture, Food and Environment (SAFE), University of Foggia, Via Napoli, 25, 71122 Foggia, Italy
}

\begin{abstract}
The aim of the present research was to evaluate the effects of protein level and flaxseed supplementation on the yield and quality of buffalo milk. In particular, the fatty acid profile of milk from buffalo cows subjected to different diets has been investigated. A $2 \times 3$ factorial design was tested with buffalo cows receiving 2 dietary crude protein $(\mathrm{CP})$ and 3 flaxseed (FS) supplementation levels. Treatments were (1) low dietary CP level $[12 \%$ of dry matter (DM)] and no flaxseed supplementation (LP); (2) low dietary CP level (12\% of DM) and low flaxseed supplementation (500 g/d) (LPFS500); (3) low dietary CP level (12\% of DM) and moderate flaxseed supplementation (1,000 g/d) (LPFS1000); (4) moderate dietary CP level (15\% of DM) and no flaxseed supplementation (MP); (5) moderate dietary CP level (15\% of DM) and low flaxseed supplementation $(500 \mathrm{~g} / \mathrm{d})$ (MPFS500); and (6) moderate dietary CP level ( $15 \%$ of DM) and moderate flaxseed supplementation $(1,000 \mathrm{~g} / \mathrm{d})$ (MPFS1000). Milk protein and casein were affected by flaxseed supplementation being higher in MP, intermediate in LP, and lower in flaxseed-supplemented diets. However, the results from the present study highlighted that low protein diets sustained milk yield, protein, and casein synthesis in milk when whole flaxseed was administered. Short-chain fatty acids, in particular C8:0 and C10:0, were the lowest in milk from buffalo cows fed the highest level of flaxseed supplementation. Medium-chain fatty acids were the lowest in FS1000, intermediate in FS500, and the highest in the HP and LP groups. Long-chain fatty acids were the highest in FS1000, intermediate in FS500 groups, and the lowest in milk from buffalo receiving no flaxseed supplementation. Protein level of the diet influenced the percentage of $\mathrm{C} 18: 0$, which was higher in MP than LP groups. Total conjugated linoleic acid content evidenced the same trend of long-chain fatty acids, with an increase of about 7\% in FL500 and of $22 \%$ in FL1000
\end{abstract}

Received March 23, 2016.

Accepted June 8, 2016.

${ }^{1}$ Corresponding author: antonella.santillo@unifg.it than the control. Apart from protein level of the diet, atherogenic index, thrombogenic index, and n-6/n-3 were the lowest in FS1000 groups; thrombogenic index and $n-6 / n-3$ were intermediate in milk from animals receiving FS500. Nutritional value of the acidic profile in buffalo milk is influenced by flaxseed supplementation, and its improvement reflects the level of dietary flaxseed supplementation.

Key words: buffalo cow, flaxseed, dietary protein, fatty acids, conjugated linoleic acid

\section{INTRODUCTION}

Water buffalo account for the second most widely available milk source in countries around the world. Within European countries, Italy accounts for 95\% of all water buffalo, with 214,164 lactating buffalo (FAOSTAT, 2016) that are mainly reared in central and southern regions of Lazio, Campania, and Puglia (Borghese et al., 2000). The milk of this species accounts for over $50 \%$ of drinking milk in countries such as India, Pakistan, Egypt, and Nepal, whereas in Italy buffalo milk is used almost exclusively for mozzarella cheese production (Zicarelli, 2004).

Several authors reported that the protein concentration used in lactating buffalo diets can be equal to or below $12 \% \mathrm{DM}$, as these concentrations have little influence on the quality and quantity of milk yield (Verna et al., 1992; Campanile et al., 1998). However, Tweatia and Bathia (1996) stated that the ideal protein content was between 11 and $14 \% \mathrm{DM}$ in the diet to stimulate ruminal microflora. The incorporation of PUFA in the diets has been carried out in several lactating species with the aim of improving the acidic profile of milk for direct human consumption or for dairy products. Among lipid sources, flaxseed has been successfully supplemented to cow (Caroprese et al., 2010; Cattani et al., 2014; Santillo et al., 2016), sheep (Zhang et al., 2006; Caroprese et al., 2011), and goat (Nudda et al., 2006, Luna et al., 2008; Caroprese et al., 2016), leading to a better n-3 PUFA profile in milk. Sunflower oil has been identified as a dietary fat supplement capable of reducing rumen protozoa for the duration of its utiliza- 
tion (Ivan et al., 2001). Defaunation has been proved to increase protein utilization by rumen microorganisms that might result in increased intestinal availability of AA (Veira et al., 1983; Tufarelli et al., 2009). Moreover, reduced fauna has been found to increase milk production in dairy cattle (Moate, 1989).

To the best of our knowledge no studies have reported the role of both protein level and fat supplementation of the diet in lactating buffalo cows. It would be useful to gain information on the effect of fat supplementation on the efficiency of utilization of dietary protein in terms of production and composition of buffalo milk. Therefore, the aim of the present research was to evaluate the effects of dietary protein level and flaxseed supplementation on the yield and quality of buffalo milk. In particular, the fatty acid profile of milk from buffalo cows subjected to different diets was investigated.

\section{MATERIALS AND METHODS}

\section{Experimental Design}

The experiment was conducted in a dairy farm located in Foggia (Apulia region, Italy). The experiment included 48 Mediterranean buffalo cows during mid lactation $(175 \pm 22 \mathrm{DIM} ; \pm \mathrm{SD})$; animals were homogeneous for age $(52 \pm 6 \mathrm{mo})$, BW $(561 \pm 15 \mathrm{~kg})$, parity $(2.08 \pm 0.28)$, milk production $(8.9 \pm 0.80 \mathrm{~kg} /$ day), milk fat $(8.56 \pm 0.9 \%)$, protein $(4.73 \pm 0.4 \%)$ content, and for fatty acids composition grouped as
SFA, MUFA, PUFA, and CLA. A $2 \times 3$ factorial design was tested with buffalo cows receiving 2 dietary $\mathrm{CP}$ and 3 flaxseed (FS) supplementation levels. Treatments were (1) low dietary CP level (12\% of DM) and no flaxseed supplementation (LP); (2) low dietary CP level $(12 \%$ of DM) and low flaxseed supplementation (500 g/d; LPFS500); (3) low dietary CP level (12\% of DM) and moderate flaxseed supplementation $(1,000$ g/d; LPFS1000); (4) moderate dietary CP level (15\% of DM) and no flaxseed supplementation (MP); 5) moderate dietary CP level (15\% of DM) and low flaxseed supplementation (500 g/d; MPFS500); and (6) moderate dietary CP level (15\% of DM) and moderate flaxseed supplementation (1,000 g/d; MPFS1000).

Animals were assigned randomly to 1 of the 6 groups subjected to the different diets and received a diet based on concentrate mainly composed of corn silage, wheat middlings, corn and soy flour, vetch and oat hay, and straw; the corn and soy flour were used to modulate the protein content of the MP and LP diets. Chemical composition and milk forage units of the experimental diets are reported in Table 1. The chemical composition of diets was determined with standard procedures (AOAC, 1990). The flaxseed groups received the same diets of MP and LP in which 500 (FS500) and 1,000 $\mathrm{g} / \mathrm{d}$ (FS1000) of concentrate was substituted with the same amount of whole flaxseed (Lin Tech, Tecnozoo srl, Torreselle di Piombino Dese, Italy).

The experiment lasted $7 \mathrm{wk}$; the first $2 \mathrm{wk}$ were considered an adaptation period and the measurements

Table 1. Ingredients, chemical composition, and milk forage unit (MFU) of the experimental diets (\% on DM basis)

\begin{tabular}{lrrrrrr}
\hline & \multicolumn{7}{c}{ Diet $^{1}$} \\
\cline { 2 - 6 } Item & MP & LP & MPFL500 & LPFL500 & MPFL1000 & LPFL1000 \\
\hline Ingredient & & & & & & \\
Corn silage & 35.06 & 36.40 & 34.63 & 35.66 & 33.23 & 35.59 \\
Wheat middlings & 10.40 & 10.80 & 9.86 & 10.89 & 7.61 & 8.77 \\
Straw & 13.40 & 13.81 & 13.29 & 13.93 & 13.50 & 13.62 \\
Vetch and oat hay & 15.43 & 16.02 & 15.42 & 16.10 & 15.51 & 15.79 \\
Soy & 15.61 & 11.04 & 15.36 & 8.73 & 14.19 & 8.02 \\
Corn & 10.41 & 14.34 & 8.62 & 11.70 & 10.44 & 12.40 \\
Flaxseed & - & - & 2.77 & 2.91 & 5.45 & 5.69 \\
Chemical composition & 2.69 & 2.79 & 3.84 & 3.86 & 4.90 & 4.93 \\
Ether extract & 14.89 & 12.35 & 14.93 & 12.24 & 14.95 & 12.36 \\
CP & 33.03 & 34.50 & 31.89 & 33.10 & 32.45 & 33.53 \\
NSC & 25.53 & 25.93 & 25.83 & 26.04 & 25.92 & 26.29 \\
ADF & 45.61 & 44.90 & 44.12 & 44.79 & 44.20 & 45.04 \\
NDF & 3.95 & 4.06 & 4.16 & 4.28 & 4.37 & 4.50 \\
ADL & 0.87 & 0.86 & 0.89 & 0.88 & 0.88 & 0.87 \\
MFU & & & & & \\
\hline
\end{tabular}

${ }^{1} \mathrm{LP}=$ low dietary CP level $(12 \%$ of DM) and no flaxseed supplementation; LPFS500 = low dietary CP level $(12 \%$ of DM) and low flaxseed supplementation $(500 \mathrm{~g})$; LPFS1000 = low dietary CP level (12\% of DM) and moderate flaxseed supplementation $(1,000 \mathrm{~g}) ; \mathrm{MP}=$ moderate dietary $\mathrm{CP}$ level $(15 \%$ of $\mathrm{DM})$ and no flaxseed supplementation; MPFS500 = moderate dietary CP level $(15 \%$ of DM) and low flaxseed supplementation (500 g); MPFS1000 = moderate dietary CP level $(15 \%$ of DM) and moderate flaxseed supplementation $(1,000 \mathrm{~g})$. 
were made during the last 5 wk. Buffalo cows were housed in cement paddocks with free access to water and were fed twice daily. The total amount of flaxseed was given before the morning feeding to each buffalo cow of the FS groups; we checked that each animal consumed the total quantity of food and supplement given. Cows were milked mechanically twice daily at 0600 and $1800 \mathrm{~h}$ and milk production was recorded at each milking. Milk collection was done once a week on the same day throughout the experiment. Individual milk samples were obtained by mixing milk from the morning and afternoon milkings in an amount proportional to milk yield. Individual milk samples were stored under refrigeration and transferred to laboratory for analyses.

\section{Milk Analyses}

Individual milk samples were analyzed for fat, protein, casein, lactose, and urea content (MilkoScan FT 120; Foss Electric A/S, Hillerød, Denmark), and SCC (Fossomatic Minor, Foss Electric A/S). Energy-corrected milk (740 kcal) was calculated using the formula reported by Campanile et al. (1998).

Fatty acids extraction from milk samples was performed as described by Feng et al. (2004), with some modifications. Briefly, $30 \mathrm{~mL}$ of bulk milk was centrifuged at $17,800 \times g$ for $45 \mathrm{~min}$ at $4^{\circ} \mathrm{C}$. Then, $1.0 \mathrm{~g}$ of fat was transferred into a microtube, left at room temperature for $30 \mathrm{~min}$, and centrifuged at 19,300 $\times$ $g$ for $40 \mathrm{~min}$ at $20^{\circ} \mathrm{C}$. Fatty acid methyl esters were then obtained as described in IDF (2002). One hundred milligrams of upper layer fat was placed into a $16-\times$ 25-mm screw-cap Pyrex tube, into which $5 \mathrm{~mL}$ of hexane and $0.2 \mathrm{~mL}$ of methanolic $2 \mathrm{~N} \mathrm{KOH}$ were added. The tube was vortexed, left to stand for $5 \mathrm{~min}$ in the dark, and then $0.5 \mathrm{~g}$ of $\mathrm{NaHSO}_{4} \times \mathrm{H}_{2} \mathrm{O}$ was added. The hexane layer, containing the FAME, was placed into a GC vial; the vial was capped and placed at $-20^{\circ} \mathrm{C}$ until GC analysis. The fatty acid composition of milk extracts was determined by capillary GC on an HP-88, $100-\mathrm{m} \times 0.25-\mathrm{mm} \times 0.20-\mu \mathrm{m}$ capillary column (Agilent Technologies Inc., Santa Clara, CA) installed on an Agilent Technologies 6890N GC equipped with a flameionization detector and a split injector. The initial oven temperature was $70^{\circ} \mathrm{C}$, held for $4 \mathrm{~min}$, subsequently increased to $175^{\circ} \mathrm{C}$ at a rate of $13^{\circ} \mathrm{C} / \mathrm{min}$, held for 27 min, increased to $215^{\circ} \mathrm{C}$ at a rate of $4^{\circ} \mathrm{C} / \mathrm{min}$, and held for $45 \mathrm{~min}$. Helium was used as the carrier gas and the column head pressure was $175 \mathrm{kPa}$. Both the injector and the detector were set at $250^{\circ} \mathrm{C}$; the split ratio was 20:1. Fatty acids were identified by comparing their retention times with the fatty acid methyl standards
(FIM-FAME-7-Mix, Matreya LLC, Pleasant Gap, PA), added to C18:1 trans-11, C18:2 cis-9,trans-11, C18:2 cis-9,cis-11, C18:2 trans-9,trans-11, and C18:2 trans10,cis-12 (Matreya LLC); peak areas were quantified using Agilent Chemstation software.

Atherogenic (ArI) and thrombogenic (TI) indexes were calculated according to Ulbricht and Southgate (1991):

$$
\begin{gathered}
\text { ArI }=(\mathrm{C} 12: 0+4 \times \mathrm{C} 14: 0+\mathrm{C} 16: 0) /[\Sigma \text { MUFA } \\
+\Sigma \operatorname{PUFA}(\mathrm{n}-6 \text { and } \mathrm{n}-3)] ; \text { and } \\
\mathrm{TI}=(\mathrm{C} 14: 0+\mathrm{C} 16: 0+\mathrm{C} 18: 0) /[0.5 \times \Sigma \mathrm{MUFA} \\
+0.5 \times \Sigma \mathrm{PUFA}(\mathrm{n}-6)+3 \times \Sigma \mathrm{PUFA}(\mathrm{n}-3) \\
+(\mathrm{n}-3) /(\mathrm{n}-6)] .
\end{gathered}
$$

The $\Delta^{9}$-desaturation indexes were calculated according to Schennink et al. (2008) as follows:

$$
\begin{gathered}
\text { C14 index }= \\
[\mathrm{C} 14: 1 \text { cis-9/(C14:0 }+\mathrm{C} 14: 1 \text { cis- } 9)] \times 100 ; \\
\mathrm{C} 16 \text { index }= \\
{[\mathrm{C} 16: 1 \text { cis-9/(C16:0 }+\mathrm{C} 16: 1 \text { cis-9) }] \times 100 ; \text { and }} \\
\mathrm{C} 18 \text { index }= \\
{[\mathrm{C} 18: 1 \text { cis-9/(C18:0 }+\mathrm{C} 18: 1 \text { cis-9) }] \times 100 .}
\end{gathered}
$$

\section{Statistical Analysis}

All variables were tested for normality using the Shapiro-Wilk test (Shapiro and Wilk, 1965). Data on milk were processed using ANOVA for repeated measures (SAS Institute, 2011). The model included protein level, flaxseed supplementation level, and their interactions as nonrepeated factors and time of sampling and its interactions as repeated factors. Individual animal variations within protein level and flaxseed supplementation level were used as error terms. When significant effects were found (at $P<0.05$ ), the Tukey test was used as a post hoc test.

\section{RESULTS AND DISCUSSION}

Yield and composition of milk from buffalo cows subjected to different feeding regimens are presented in Table 2. In our study, fat content was not influenced by the dietary treatments, although low-protein diets tended to have lower milk fat content. In buffalo cows, 
Table 2. Yield and composition of milk from buffalo cows subjected to different feeding regimens ${ }^{1}$

\begin{tabular}{|c|c|c|c|c|c|c|c|}
\hline Item & $\begin{array}{l}\text { Protein } \\
\text { level }\end{array}$ & \multicolumn{3}{|c|}{ Flaxseed } & SEM & \multicolumn{2}{|c|}{ Effect, $P$-value } \\
\hline Milk yield, kg/d & MP & 9.14 & 8.51 & 7.75 & & & \\
\hline \multirow[t]{2}{*}{ ECM yield, kg/d } & MP & $16.19^{\mathrm{b}}$ & $12.42^{\mathrm{a}}$ & $13.12^{\mathrm{a}}$ & & & \\
\hline & $\mathrm{LP}$ & $15.09^{\mathrm{ab}}$ & $16.02^{\mathrm{b}}$ & $14.35^{\mathrm{ab}}$ & 1.05 & NS & $*$ \\
\hline Fat, $\%$ & MP & 9.91 & 8.77 & 10.06 & & & \\
\hline Protein, $\%$ & LP & $4.8^{\mathrm{ab}}$ & $4.74^{\mathrm{a}}$ & $4.71^{\mathrm{a}}$ & 0.08 & NS & * \\
\hline \multirow[t]{2}{*}{ Casein, \% } & MP & $3.89^{\mathrm{b}}$ & $3.71^{\mathrm{a}}$ & $3.67^{\mathrm{a}}$ & & & \\
\hline & $\mathrm{LP}$ & $3.82^{\text {ab }}$ & $3.76^{\mathrm{a}}$ & $3.71^{\mathrm{a}}$ & 0.06 & NS & $* *$ \\
\hline \multirow[t]{2}{*}{ Lactose, $\%$} & MP & 4.79 & 4.75 & 4.63 & & & \\
\hline & $\mathrm{LP}$ & 4.82 & 4.82 & 4.76 & 0.05 & NS & NS \\
\hline \multirow[t]{2}{*}{$\mathrm{pH}$} & MP & 6.72 & 6.83 & 6.72 & & & \\
\hline & LP & 6.80 & 6.79 & 6.79 & 0.02 & NS & NS \\
\hline
\end{tabular}

${ }^{\mathrm{a}, \mathrm{b}}$ Values followed by different letters differ significantly at $P<0.05$.

${ }^{1} \mathrm{LP}=$ low dietary CP level $(12 \%$ of DM) and no flaxseed supplementation; LPFS500 = low dietary CP level (12\% of DM) and low flaxseed supplementation $(500 \mathrm{~g})$; LPFS1000 = low dietary CP level $(12 \%$ of DM) and moderate flaxseed supplementation $(1,000 \mathrm{~g}) ; \mathrm{MP}=\mathrm{moderate}$ dietary CP level (15\% of DM) and no flaxseed supplementation; MPFS500 = moderate dietary CP level (15\% of DM) and low flaxseed supplementation $(500 \mathrm{~g})$; MPFS1000 = moderate dietary CP level $(15 \%$ of DM) and moderate flaxseed supplementation (1,000 g).

$* P<0.05,{ }^{* *} P<0.01$.

crushed flaxseed supplementation led to higher milk fat than control diet (El-Aziz et al., 2012), whereas no effect was reported for whole flaxseed supplementation on Holstein (Petit, 2002) and Simmental cows (Santillo et al., 2016). The effect of flaxseed on milk fat may be due to the different processing of supplemental flaxseed. Milk yield tended $(P=0.06)$ to be higher in the groups receiving the low-protein diet apart from flaxseed supplementation. Furthermore within the low-protein diet, milk yield tended $(P=0.07)$ to be lower in FS1000 than FS500. Previous research on buffalo cows supplemented with crushed flaxseed (221 or $442 \mathrm{~g} /$ animal per day) showed a significant increase of 10 to $18 \%$ milk yield with respect to the control diet (El-Aziz et al., 2012). Production was expressed as ECM and this parameter was influenced both by flaxseed $(P<0.05)$ and the interaction between protein and flaxseed $(P<0.05)$, which was higher in milk from nonsupplemented flaxseed diets; the reduction in ECM yield was lower when whole flaxseed supplementation was combined with a low-protein diet. Protein and casein content of milk was affected by flaxseed supplementation $(P<0.05$ and $P$ $<0.01$, respectively); both protein and casein was lower in flaxseed-supplemented diets. In medium-protein and high-protein diets, the association with flaxseed led to a lower concentration of milk protein than control diets without flaxseed in Holstein cows due to a decrease in the amount of microbial protein supply for milk protein synthesis (Petit et al., 2005). In buffalo cows the reduction in milk protein and casein due to flaxseed supplementation was shown to be significant only within MP diets. The results from the present study highlighted that low-protein diets sustained milk yield, protein, and casein synthesis in milk when whole flaxseed was administered. Levels of urea in milk was not different among experimental groups, with mean value of $0.03 \pm 0.008 \%$ in accordance with levels reported for buffalo milk (Campanile et al., 1998); the present results showed no differences in the efficiency of utilization of dietary nitrogen among treatments. Somatic cell count was not affected by treatments evidencing a good hygienic quality of milk, according to European Union Directives (46/92 and 71/94) that set a limit of 400,000 cells $/ \mathrm{mL}$ for SCC in buffalo milk when the milk was used for products made with raw milk. Lactose content and $\mathrm{pH}$ of milk were not affected by treatments and fell within the range reported for buffalo milk (Fox, 2003), confirming the absence of IMI in the animals involved in the trial.

Fatty acid composition of milk from buffalo cows subjected to different feeding regimens is reported in Table 3. Fatty acids grouped in short- $(P<0.01)$, medium- $(P<0.001)$, and long-chains $(P<0.001)$ were affected by flaxseed supplementation, whereas no effect was reported for dietary protein level except for myristoleic, palmitoleic, and stearic acid. Short-chain fatty acids, in particular C8:0 and C10:0, were the lowest in milk from buffalo fed the highest level of flaxseed 
supplementation. Medium-chain fatty acids were the lowest in FS1000, intermediate in FS500, and the highest in the MP and LP diets. Myristic and palmitic acids were the most represented among medium-chain fatty acids; however, the supplementation with $1,000 \mathrm{~g}$ of whole flaxseed was able to decrease lauric and palmitic acids by about 10 and 20\%, respectively, compared to control milk. Low protein levels in the diet led to higher percentages of C14:1 and C16:1 MUFA, whereas flaxseed-supplemented diets showed lower levels of the aforementioned ( $\mathrm{C} 14: 1$ and $\mathrm{C} 16: 1)$ fatty acids in milk than control diet. The $\mathrm{C} 14: 0$ is mainly synthesized de novo by the mammary gland and C14:1 from the desaturation of C14:0 (Corl et al., 2001), whereas the mammary gland produces half the palmitic acid (Mansbridge and Blake, 1997). Furthermore, ruminal protozoa are an important source of lipids for the host animal (Or-Rashid et al., 2007) and have a higher concentration of C16:0 than bacteria (Váradyová et al.,
2008). The lower percentages of C16:0 in FS groups may be regarded as an outcome of the fat source and level on the ruminal ability to produce fatty acids. It was reported that supplementation with sunflower oil for sheep decreased the concentration of C16:0 in the rumen content (Toral et al., 2009). Moreover, supplementation of rice bran as a source of linoleic acid in cow led to lower concentration of milk C16:0 than control, probably due to a decreased ruminal protozoa (Castaño et al., 2014).

Long-chain fatty acids were the highest in FS1000, intermediate in FS500, and the lowest in milk from buffalo receiving no flaxseed supplementation. Protein levels of the diet influenced the percentage of $\mathrm{C} 18: 0$, which was higher in MP than LP groups, probably as a consequence of the major efficiency of the biohydrogenation process operated by ruminal microflora. Flaxseed supplementation influenced significantly the percentage of stearic, vaccenic, oleic, and linolenic acids, showing

Table 3. Fatty acid composition (\% of FAME) of milk from buffalo cows subjected to different feeding regimens ${ }^{1}$

\begin{tabular}{|c|c|c|c|c|c|c|c|}
\hline \multirow[b]{2}{*}{ Item } & \multirow{2}{*}{$\begin{array}{l}\text { Protein } \\
\text { level }\end{array}$} & \multicolumn{3}{|c|}{ Flaxseed } & \multirow[b]{2}{*}{ SEM } & \multicolumn{2}{|c|}{ Effect, $P$-value } \\
\hline & & 0 & 500 & 1000 & & Protein & Flaxseed \\
\hline \multirow[t]{2}{*}{ Short-chain } & MP & $13.06^{\mathrm{b}}$ & $13.24^{\mathrm{b}}$ & $11.63^{\mathrm{a}}$ & & & \\
\hline & LP & $13.87^{\mathrm{b}}$ & $13.02^{\mathrm{b}}$ & $11.83^{\mathrm{a}}$ & 0.4 & NS & $* *$ \\
\hline \multirow[t]{2}{*}{$\mathrm{C} 8: 0$} & MP & $1.37^{\mathrm{b}}$ & $1.44^{\mathrm{b}}$ & $1.11^{\mathrm{a}}$ & & & \\
\hline & LP & $1.39^{\mathrm{b}}$ & $1.45^{\mathrm{b}}$ & $1.22^{\mathrm{a}}$ & 0.03 & NS & $* *$ \\
\hline \multirow[t]{2}{*}{$\mathrm{C} 10: 0$} & MP & $2.41^{\mathrm{b}}$ & $2.49^{\mathrm{b}}$ & $1.91^{\mathrm{a}}$ & & & \\
\hline & LP & $2.78^{\mathrm{c}}$ & $2.49^{\mathrm{b}}$ & $1.99^{\mathrm{a}}$ & 0.08 & NS & * \\
\hline \multirow{2}{*}{ Medium-chain } & MP & $51.44^{\mathrm{c}}$ & $48.61^{\mathrm{b}}$ & $42.61^{\mathrm{a}}$ & & & \\
\hline & LP & $53.11^{\mathrm{c}}$ & $48.34^{\mathrm{b}}$ & $42.56^{\mathrm{a}}$ & 0.57 & NS & $* * *$ \\
\hline \multirow[t]{2}{*}{ C14:0 } & MP & $11.95^{\mathrm{b}}$ & $12.23^{\mathrm{b}}$ & $10.78^{\mathrm{a}}$ & & & \\
\hline & LP & $12.46^{\mathrm{b}}$ & $12.47^{\mathrm{b}}$ & $11.08^{\mathrm{a}}$ & 0.2 & NS & $* * *$ \\
\hline \multirow[t]{2}{*}{ C14:1 } & MP & $0.98^{\mathrm{b}}$ & $0.65^{\mathrm{a}}$ & $0.83^{\mathrm{a}}$ & & & \\
\hline & LP & $1.2^{\mathrm{b}}$ & $1.12^{\mathrm{b}}$ & $0.93^{\mathrm{ab}}$ & 0.09 & * & $* *$ \\
\hline \multirow[t]{2}{*}{$\mathrm{C} 16: 0$} & MP & $33.9^{\mathrm{c}}$ & $30.79^{\mathrm{b}}$ & $27.39^{\mathrm{a}}$ & & & \\
\hline & LP & $34.39^{\mathrm{c}}$ & $30.35^{\mathrm{b}}$ & $26.77^{\mathrm{a}}$ & 0.6 & NS & $* * *$ \\
\hline \multirow[t]{2}{*}{ C16:1 } & MP & $1.7^{\mathrm{b}}$ & $1.53^{\mathrm{ab}}$ & $1.32^{\mathrm{a}}$ & & & \\
\hline & LP & $2.22^{\mathrm{c}}$ & $1.43^{\mathrm{a}}$ & $1.43^{\mathrm{a}}$ & 0.1 & $*$ & $* * *$ \\
\hline \multirow{2}{*}{ Long-chain } & MP & $32.75^{\mathrm{a}}$ & $35.97^{\mathrm{b}}$ & $43.18^{\mathrm{c}}$ & & & \\
\hline & LP & $30.28^{\mathrm{a}}$ & $36.32^{\mathrm{b}}$ & $43.35^{\mathrm{c}}$ & 0.84 & NS & $* * *$ \\
\hline \multirow{2}{*}{$\mathrm{C} 18: 0$} & MP & $8.27^{\mathrm{b}}$ & $9.18^{\mathrm{c}}$ & $12.2^{\mathrm{d}}$ & & & \\
\hline & LP & $6.79^{\mathrm{a}}$ & $9.13^{\mathrm{c}}$ & $11.64^{\mathrm{d}}$ & 0.26 & $*$ & $* * *$ \\
\hline \multirow[t]{2}{*}{ C18:1 trans-11 } & MP & $3.74^{\mathrm{ab}}$ & $4.27^{\mathrm{bc}}$ & $4.88^{\mathrm{d}}$ & & & \\
\hline & $\mathrm{LP}$ & $3.35^{\mathrm{a}}$ & $4.09^{\mathrm{bc}}$ & $4.48^{\mathrm{cd}}$ & 0.15 & NS & $* * *$ \\
\hline \multirow[t]{2}{*}{ C18:1 cis-9 } & MP & $16.3^{\mathrm{a}}$ & $17.79^{\mathrm{b}}$ & $21.05^{\mathrm{c}}$ & & & \\
\hline & LP & $15.95^{\mathrm{a}}$ & $18.13^{\mathrm{b}}$ & $22.42^{\mathrm{c}}$ & 0.66 & NS & $* * *$ \\
\hline \multirow[t]{2}{*}{ C18:3n-3 } & MP & $0.27^{\mathrm{a}}$ & $0.42^{\mathrm{b}}$ & $0.58^{\mathrm{d}}$ & & & \\
\hline & LP & $0.26^{\mathrm{a}}$ & $0.48^{\mathrm{bc}}$ & $0.56^{\mathrm{cd}}$ & 0.03 & NS & $* * *$ \\
\hline \multirow[t]{2}{*}{ Total CLA } & MP & $1.17^{\mathrm{a}}$ & $1.23^{\mathrm{b}}$ & $1.45^{\mathrm{c}}$ & & & \\
\hline & LP & $1.08^{\mathrm{a}}$ & $1.29^{\mathrm{b}}$ & $1.42^{\mathrm{c}}$ & 0.04 & NS & $* * *$ \\
\hline
\end{tabular}

${ }^{\mathrm{a}-\mathrm{d}}$ Values followed by different letters differ significantly at $P<0.05$.

${ }^{1} \mathrm{LP}=$ low dietary CP level $(12 \%$ of DM) and no flaxseed supplementation; LPFS500 = low dietary CP level $(12 \%$ of DM) and low flaxseed supplementation (500 g); LPFS1000 = low dietary CP level (12\% of DM) and moderate flaxseed supplementation $(1,000 \mathrm{~g}) ; \mathrm{MP}=$ moderate dietary $\mathrm{CP}$ level $(15 \% \mathrm{of} \mathrm{DM})$ and no flaxseed supplementation; MPFS500 = moderate dietary CP level (15\% of DM) and low flaxseed supplementation (500 g); MPFS1000 = moderate dietary CP level $(15 \%$ of DM) and moderate flaxseed supplementation $(1,000 \mathrm{~g})$. ${ }^{*} P<0.05,{ }^{* *} P<0.01,{ }^{* * *} P<0.001$. 
that the level of linolenic acid and of the intermediates of its biohydrogenation in milk reflected the level of dietary FS supplementation. In particular, vaccenic acid is produced in the rumen and then absorbed by the gut to be transported in the mammary gland, where it is used for endogenous synthesis of rumenic acid through stearoyl-CoA desaturase activity (Luna et al., 2008).

Total CLA content showed the same trend of longchain fatty acids, with an increase of about $7 \%$ in FS500 and of $22 \%$ in FS1000 than the control. El-Aziz et al. (2012) reported an elevation by about $50 \%$ in the level of milk CLA in buffalo cows fed crushed flaxseed rather than control diet. In previous experiments on Simmental and Holstein-Friesian cow milk, a slight but not significant increase was reported for CLA in milk of whole flaxseed supplementation $(1,000 \mathrm{~g} / \mathrm{d})$ with respect to the control (Cattani et al., 2014; Santillo et al., 2016); however, in Italian Friesian cows administration of $1,200 \mathrm{~g} / \mathrm{d}$ per cow of whole flaxseed resulted in a significant increase of CLA content in milk (Caroprese et al., 2010). The different behavior of CLA content in different species and breeds fed whole flaxseed may be ascribed to the different gene expression and activity of stearoyl-CoA desaturase in the mammary gland. Indeed, compared with the homologous genes in cattle, sheep, and goat, the river buffalo stearoyl CoA de- saturase is characterized by a higher genetic variability (Pauciullo et al., 2010).

Saturated fatty acids, MUFA, PUFA, ArI and TI indexes, and desaturase indexes of milk from buffalo cows subjected to different feeding regimens are reported in Table 4. Saturated fatty acids, MUFA, PUFA, ArI, TI, and n- $6 / n-3$ were influenced only by flaxseed supplementation $(P<0.001)$. Saturated fatty acids and MUFA were the lowest and the highest in FS1000, respectively. Polyunsaturated fatty acids were the highest in milk from buffalo receiving flaxseed supplementation compared with the control milk. Atherogenic index, TI, and n-6/n-3 were always the lowest in FS1000 groups, and TI and n- $6 / \mathrm{n}-3$ were intermediate in milk from animals receiving FS500. The modifications of nutritional indexes in milk showed the role of flaxseed supplementation on the health properties of buffalo milk. The $\Delta^{9}$-desaturation indexes of $\mathrm{C} 14: 0, \mathrm{C} 16: 0$, and $\mathrm{C} 18: 0$ can be an estimate of its activity (Jacobs et al., 2011) or its concentration (Feng et al., 2004); these indexes were influenced by both protein level and flaxseed supplementation. The $\Delta^{9}$-desaturation indexes were the highest in milk from the low-protein diet without flaxseed supplementation. In particular, within protein level significant differences emerged within MP and LP diets, with the latter showing consistently higher values

Table 4. Saturated fatty acids, MUFA, PUFA, nutritional indexes, and desaturation indexes of milk from buffalo cows subjected to different feeding regimens ${ }^{1}$

\begin{tabular}{|c|c|c|c|c|c|c|c|}
\hline \multirow[b]{2}{*}{ Item } & \multirow{2}{*}{$\begin{array}{l}\text { Protein } \\
\text { level }\end{array}$} & \multicolumn{3}{|c|}{ Flaxseed } & \multirow[b]{2}{*}{ SEM } & \multicolumn{2}{|c|}{ Effect, $P$-value ${ }^{2}$} \\
\hline & & 0 & 500 & 1000 & & Protein & Flaxseed \\
\hline \multirow[t]{2}{*}{$\overline{\mathrm{SFA}}$} & MP & $73.37^{\mathrm{b}}$ & $71.27^{\mathrm{b}}$ & $67.26^{\mathrm{a}}$ & & & \\
\hline & LP & $73.48^{\mathrm{b}}$ & $70.78^{\mathrm{b}}$ & $66.29^{\mathrm{a}}$ & 0.81 & NS & $* * *$ \\
\hline \multirow[t]{2}{*}{ MUFA } & MP & $23.12^{\mathrm{a}}$ & $24.92^{\mathrm{a}}$ & $28.53^{\mathrm{b}}$ & & & \\
\hline & LP & $23.17^{\mathrm{a}}$ & $25.14^{\mathrm{a}}$ & $29.68^{\mathrm{b}}$ & 0.75 & NS & $* * *$ \\
\hline \multirow[t]{2}{*}{ PUFA } & MP & $3.8^{\mathrm{a}}$ & $4.14^{\mathrm{b}}$ & $4.44^{\mathrm{b}}$ & & & \\
\hline & LP & $3.56^{\mathrm{a}}$ & $4.43^{\mathrm{b}}$ & $4.21^{\mathrm{b}}$ & 0.12 & NS & $* * *$ \\
\hline \multirow[t]{2}{*}{$\mathrm{AI}$} & MP & $3.28^{\mathrm{b}}$ & $2.95^{\mathrm{b}}$ & $2.34^{\mathrm{a}}$ & & & \\
\hline & $\mathrm{LP}$ & $3.37^{\mathrm{b}}$ & $3.04^{\mathrm{b}}$ & $2.22^{\mathrm{a}}$ & 0.15 & NS & $* * *$ \\
\hline \multirow[t]{2}{*}{$\mathrm{TI}$} & MP & $3.87^{\mathrm{c}}$ & $3.37^{\mathrm{b}}$ & $2.86^{\mathrm{a}}$ & & & \\
\hline & LP & $3.86^{\mathrm{c}}$ & $3.4^{\mathrm{b}}$ & $2.7^{\mathrm{a}}$ & 0.12 & NS & $* * *$ \\
\hline \multirow[t]{2}{*}{$n-6 / n-3$} & MP & $9.23^{\mathrm{c}}$ & $7.09^{\mathrm{b}}$ & $5.76^{\mathrm{a}}$ & & & \\
\hline & $\mathrm{LP}$ & $9.53^{\mathrm{c}}$ & $7.23^{\mathrm{b}}$ & $5.54^{\mathrm{a}}$ & 0.24 & NS & $* * *$ \\
\hline \multirow{2}{*}{$\Delta^{9} \mathrm{C} 14$} & MP & $7.87^{\mathrm{ab}}$ & $7.28^{\mathrm{a}}$ & $7.15^{\mathrm{a}}$ & & & \\
\hline & $\mathrm{LP}$ & $9.22^{\mathrm{c}}$ & $8.3^{\mathrm{b}}$ & $7.8^{\mathrm{a}}$ & 0.3 & $* *$ & * \\
\hline \multirow[t]{2}{*}{$\Delta^{9} \mathrm{C} 16$} & MP & $5.16^{\mathrm{a}}$ & $4.78^{\mathrm{a}}$ & $4.56^{\mathrm{a}}$ & & & \\
\hline & LP & $6.32^{\mathrm{b}}$ & $4.82^{\mathrm{a}}$ & $5.08^{\mathrm{a}}$ & 0.2 & * & $* * *$ \\
\hline \multirow{2}{*}{$\Delta^{9} \mathrm{C} 18$} & MP & $67.35^{\mathrm{a}}$ & $66.02^{\mathrm{a}}$ & $62.02^{\mathrm{a}}$ & & & \\
\hline & LP & $71.05^{\mathrm{b}}$ & $67.08^{\mathrm{a}}$ & $65.73^{\mathrm{a}}$ & 1.2 & $* *$ & $* * *$ \\
\hline
\end{tabular}

${ }^{a-c}$ Values followed by different letters differ significantly at $P<0.05$.

${ }^{1} \mathrm{LP}=$ low dietary $\mathrm{CP}$ level $(12 \%$ of DM) and no flaxseed supplementation; LPFS500 = low dietary CP level $(12 \%$ of DM) and low flaxseed supplementation $(500 \mathrm{~g})$; LPFS1000 = low dietary CP level (12\% of DM) and moderate flaxseed supplementation $(1,000 \mathrm{~g}) ; \mathrm{MP}=$ moderate dietary $\mathrm{CP}$ level $(15 \%$ of $\mathrm{DM})$ and no flaxseed supplementation; MPFS500 = moderate dietary CP level (15\% of DM) and low flaxseed supplementation (500 $\mathrm{g})$; MPFS1000 = moderate dietary $\mathrm{CP}$ level $(15 \%$ of DM $)$ and moderate flaxseed supplementation $(1,000 \mathrm{~g})$. ${ }^{*} P<0.05,{ }^{* *} P<0.01,{ }^{* * *} P<0.001$. 
for desaturase indexes. Flaxseed supplementation evidenced a reduction of desaturase indexes respect to the control groups. Although the concentrations of C14:1, C16:1, and C18:1 in milk increased with the inclusion of flaxseed in the diet but the desaturase indexes did not follow the same trend, suggesting that the increase of these UFA was not related to an increase in $\Delta^{9}$ desaturase activity. The same behavior was observed also in sheep supplemented with grape seed and linseed alone or in combination respect to a control diet (Correddu et al., 2016).

In conclusion, a protein level in the diet of $12 \% \mathrm{CP}$ or DM sustained the yield and composition, in terms of protein and casein synthesis, of buffalo milk. Fatty acids grouped in short, medium, and long chains were mainly affected by flaxseed supplementation, whereas dietary protein level had a minor effect. In particular, flaxseed supplementation significantly influenced the percentage of stearic, vaccenic, oleic, and linolenic acids, with a reduction of SFA and an increase of linolenic acid and the intermediates of its biohydrogenation in milk. Furthermore, total CLA content increased about $7 \%$ in FS500 and 22\% in FS1000 compared to control milk. Nutritional value of the acidic profile in buffalo milk is influenced by dietary flaxseed supplementation, and its improvement reflects the level of flaxseed supplementation.

\section{REFERENCES}

AOAC. 1990. Official Methods of Analysis. 15th ed. Assoc. Off. Anal. Chem., Arlington, VA.

Borghese, A., B. Moioli, and C. Tripaldi. 2000. Buffalo milk: Processing and product development in the Mediterranean countries. Pages 37-46 in Third Asian Buffalo Congress, Kandy, Sri Lanka. J. A. de S. Siriwardene, D. H. A. Subasinghe, N. U. Horadagoda, and H. Abeygunawardena, ed. National Science Foundation, Colombo, Sri Lanka.

Campanile, G., C. Defilippo, R. Di Palo, W. Taccone, and L. Zicarelli. 1998. Influence of dietary protein on urea level of blood and milk of buffalo cows. Livest. Prod. Sci. 55:135-143.

Caroprese, M., M. Albenzio, A. Bruno, V. Fedele, A. Santillo, and A. Sevi. 2011. Effect of solar radiation and flaxseed supplementation on milk production and fatty acid profile of lactating ewes under high ambient temperature. J. Dairy Sci. 94:3856-3867.

Caroprese, M., M. G. Ciliberti, A. Santillo, R. Marino, A. Sevi, and M. Albenzio. 2016. Immune response, productivity and quality of milk from grazing goats as affected by dietary polyunsaturated fatty acid supplementation. Res. Vet. Sci. 105:229-235.

Caroprese, M., A. Marzano, R. Marino, G. Gliatta, A. Muscio, and A. Sevi. 2010. Flaxseed supplementation improves fatty acid profile of cow milk. J. Dairy Sci. 93:2580-2588.

Castaño, G. A., M. L. Pabón, and J. E. Carulla. 2014. Concentration of trans-vaccenic and rumenic acids in the milk from grazing cows supplemented with palm oil, rice bran or whole cottonseed. Rev. Bras. Zootec. 43:315-326.

Cattani, M., R. Mantovani, S. Schiavon, G. Bittante, and L. Bailoni. 2014. Recovery of n-3 polyunsaturated fatty acids and conjugated linoleic acids in ripened cheese obtained from milk of cows fed different levels of extruded flaxseed. J. Dairy Sci. 97:123-135.
Corl, B. A., L. H. Baumgard, D. A. Dwyer, J. M. Griinari, B. S. Phillips, and D. E. Bauman. 2001. The role of $\Delta^{9}$-desaturase in the production of cis-9,trans-11 CLA. J. Nutr. Biochem. 12:622-630.

Correddu, F., G. Gaspa, G. Pulina, and A. Nudda. 2016. Grapeseed and linseed, alone and in combination, enhance unsaturated fatty acids in the milk of Sarda dairy sheep. J. Dairy Sci. 99:1725-1735.

El-Aziz, M. A., S. M. Kholif, and T. A. Morsy. 2012. Buffalo's milk composition and its fat properties as affected by feeding diet supplemented with flaxseed or fibrolytic enzymes in early lactation. J. Life Sci. 4:19-25.

FAOSTAT. 2016. Production: Live animals. Food and Agriculture Organization of the United Nations. Accessed Mar. 14, $2016 . \quad$ http://faostat.fao.org/site/573/DesktopDefault. aspx?PageID $=573 \#$ ancor.

Feng, S., A. L. Lock, and P. C. Garnsworthy. 2004. A rapid method for determining fatty acid composition of milk. J. Dairy Sci. $87: 3785-3788$.

Fox, P. F. 2003. Milk. Pages 1805-1812 in Encyclopedia of Dairy Sciences. Vol. 1. H. Roginski, J. W. Fuquay, and P. F. Fox, ed. MPG Books, Bodmin, Cornwall, UK.

IDF (International Dairy Federation). 2002. Milk fat-Preparation of fatty acid methyl esters. International standard ISO 15884-IDF 182:2002. IDF, Brussels, Belgium.

Ivan, M., P. S. Mir, K. M. Koenig, L. M. Rode, L. Neil, T. Entz, and Z. Mir. 2001. Effects of dietary sunflower oil on rumen protozoa population and tissue concentration of conjugated linoleic acid in sheep. Small Rumin. Res. 41:215-227.

Jacobs, A. A., J. van Baal, M. A. Smits, H. Z. H. Taweel, W. H. Hendriks, A. M. van Vuuren, and J. Dijkstra. 2011. Effects of feeding rapeseed oil, soybean oil, or linseed oil on stearoyl-CoA desaturase expression in the mammary gland of dairy cows. J. Dairy Sci. 94:874-887.

Luna, P., A. Bach, M. Juarez, and M. A. de la Fuente. 2008. Effect of a diet enriched in whole linseed and sunflower oil on goat milk fatty acid composition and conjugated linoleic acid isomer profile. J. Dairy Sci. 91:20-28.

Mansbridge, R. J., and J. S. Blake. 1997. Nutritional factors affecting the fatty acid composition of bovine milk. Br. J. Nutr. 78(Suppl. 1):S37-S47.

Moate, P. J. 1989. Defaunation increases milk yield of dairy cows. Page 18A in Recent Advances in Animal Nutrition in Australia. D. J. Farrell, ed. University of New England Printery, Armidale, NSW, Australia.

Nudda, A., G. Battacone, M. G. Usai, S. Fancellu, and G. Pulina. 2006. Supplementation with extruded linseed cake affects concentrations of conjugated linoleic acid and vaccenic acid in goat milk. J. Dairy Sci. 89:277-282.

Or-Rashid, M. M., N. E. Odongo, and B. W. McBride. 2007. Fatty acid composition of ruminal bacteria and protozoa, with emphasis on conjugated linoleic acid, vaccenic acid, and odd-chain and branchedchain fatty acids. J. Anim. Sci. 85:1228-1234.

Pauciullo, A., G. Cosenza, A. D'Avino, L. Colimoro, D. Nicodeoa, A. Coletta, M. Feligini, C. Marchitelli, D. Di Berardino, and L. Ramunno. 2010. Sequence analysis and genetic variability of stearoyl CoA desaturase (SCD) gene in the Italian Mediterranean river buffalo. Mol. Cell. Probes 24:407-410.

Petit, H. V. 2002. Digestion, milk production, milk composition, and blood composition of dairy cows fed whole flaxseed. J. Dairy Sci. 85:1482-1490.

Petit, H. V., M. Ivan, and P. S. Mir. 2005. Effects of flaxseed on protein requirements and $\mathrm{N}$ excretion of dairy cows fed diets with two protein concentrations. J. Dairy Sci. 88:1755-1764.

Santillo, A., M. Caroprese, R. Marino, F. d'Angelo, A. Sevi, and M. Albenzio. 2016. Fatty acid profile of milk and Cacioricotta cheese from Italian Simmental cows as affected by dietary flaxseed supplementation. J. Dairy Sci. 99:2545-2551. http://dx.doi. org $/ 10.3168 /$ jds.2015-10419.

SAS Institute. 2011. SAS User's Guide: Statistics. Version 9.2 ed. SAS Inst. Inc., Cary, NC.

Schennink, A., J. M. Heck, H. Bovenhuis, M. H. P. Visker, H. J. F. van Valenberg, and J. A. M. van Arendonk. 2008. Milk fatty acid 
unsaturation: Genetic parameters and effects of stearoyl-CoA desaturase $(S C D 1)$ and acyl CoA:diacylglycerol acyltransferase 1 (DGAT1). J. Dairy Sci. 91:2135-2143.

Shapiro, S. S., and M. Wilk. 1965. An analysis of variance test for normality. Biometrika 52:591-611.

Toral, P. G., A. Belenguer, P. Frutos, and G. Hervás. 2009. Effect of the supplementation of a high-concentrate diet with sunflower and fish oils on ruminal fermentation in sheep. Small Rumin. Res. $81: 119-125$.

Tufarelli, V., M. Dario, and V. Laudadio. 2009. Milk yield and composition of lactating Comisana ewes fed total mixed rations containing nitrogen sources with different ruminal degradability. Livest. Sci. 122:349-353.

Tweatia, B. S., and S. K. Bathia. 1996. Comparative studies in rumen ammonia anabolising enzymes, microbial and mineral profile between buffalo and cattle fed fibrous diet. Buffalo J. 12:169-179.

Ulbricht, T. L. V., and D. A. T. Southgate. 1991. Coronary heart disease: Seven dietary factors. Lancet 338:985-992.

Váradyová, Z., S. Kišidayová, P. Siroka, and D. Jalc. 2008. Comparison of fatty acid composition of bacterial and protozoal fractions in ru- men fluid of sheep fed diet supplemented with sunflower, rapeseed and linseed oils. Anim. Feed Sci. Technol. 144:44-54.

Veira, D. M., M. Ivan, and P. Y. Jui. 1983. Rumen ciliate protozoa: Effects on digestion in the stomach of sheep. J. Dairy Sci 66:1015-1022.

Verna, M., S. Bartocci, A. Amici, and M. Agostini. 1992. Effect of diets with different energetic concentration on the qualitative and quantitative yield in lactating buffaloes. Pages 258-261 in Proc. Int. Symp. Prospects of Buffalo Production in the Mediterranean and the Middle East: Proceedings of the Joint ESAP, EAAP, FAO, ICAMAS, and OIE Symposium, Cairo, Egypt. Pudoc Scientific Publishers, Wageningen, the Netherlands.

Zhang, R. H., A. F. Mustafa, and X. Zhao. 2006. Effects of flaxseed supplementation to lactating ewes on milk composition, cheese yield, and fatty acid composition of milk and cheese. Small Rumin. Res. 63:233-241.

Zicarelli, L. 2004. Buffalo milk: Its properties, dairy yield and mozzarella production. Vet. Res. Commun. 28:127-135. 